\title{
Acetylation of vitamin E by Candida antarctica lipase B immobilized on different carriers
}

Pamela TORRES, Dolores REYES-DUARTE\#, Nieves LÓPEZ-CORTÉS, Manuel FERRER, Antonio BALLESTEROS and Francisco J. PLOU*

Departamento de Biocatálisis, Instituto de Catálisis y Petroleoquímica, CSIC, Cantoblanco, 28049 Madrid, Spain.

${ }^{*}$ Correspondence author: Francisco J. Plou, Departamento de Biocatálisis, Instituto de Catálisis y Petroleoquímica, CSIC, Cantoblanco, Marie Curie 2, 28049 Madrid, Spain. Phone: +34-91-5854869; Fax: +34-91-5854760. E-mail: fplou@icp.csic.es. http://www.icp.csic.es/abg

\#Present address: Departamento de Procesos y Tecnología, División de Ciencias Naturales e Ingeniería, UAM-Unidad Cuajimalpa, México, D.F. 


\section{ABSTRACT}

We describe for the first time the enzymatic acylation of the phenolic group of tocopherols (vitamin E) by transesterification with vinyl acetate in 2-methyl-2-butanol (2M2B). Out of 15 hydrolases screened, only the lipase B from Candida antarctica (Novozym 435) catalyzed the acylation. The acetylation of $\delta$-tocopherol was faster than that of $\alpha$-tocopherol, probably due to its lower methylation degree. A series of experiments using $(R)$-Trolox and $p$-cresol as competitive acceptors of tocopherols showed that reaction rate notably diminished when increasing acceptor size. To maximize the potential of this reaction, three immobilization carriers for $C$. antarctica lipase B were studied: the ion-exchange resin Lewatit (the support in Novozym 435), a biodegradable polymer (Purasorb) and polypropylene (Accurel EP100). The acetylation of $\alpha$-tocopherol was faster with the enzyme immobilized in polypropylene, which was correlated with its higher porosity. A mixture hexane/2M2B 90:10 (v/v) was found to be the optimum medium composition, as it represents a compromise between substrates solubility and biocatalyst efficiency. The acylation process was no enantioselective, probably due to the fact that the chiral centers are separated from the phenolic group by a minimum of six bonds.

Key words: immobilization, lipases, transesterification, Novozym 435, tocopherols, antioxidants modification. 


\section{INTRODUCTION}

Antioxidants protect cells against the effects of harmful free radicals and play an important role in preventing many human diseases (e.g. cancer, atherosclerosis, stroke, rheumatoid arthritis, neurodegeneration, inflammatory disorders, diabetes) and aging itself $[1 ; 2]$. The study of antioxidants is of great interest for the role they play in protecting living systems against lipid peroxidation and other anomalous molecular modifications [3]. In addition, antioxidant molecules also prevent unsaturated oil products from becoming rancid during storage, thus extending its shelf life $[4 ; 5]$.

Among the natural antioxidants, the term vitamin $\mathrm{E}$ describes the beneficial biological activity on humans and animals of a group of structurally related compounds, in particular $\alpha-$, $\beta-, \gamma-$ and $\delta$-tocopherol, plus $\alpha-, \beta-, \gamma-$ and $\delta$-tocotrienol [6]. Vitamin $E$ enhances the oxidative stability of the organisms owing to its ability to protect polyunsaturated fatty acids from peroxidation and to scavenge free radicals. Tocopherols have three chiral centers at carbons 2, 4'- and 8'-, and the naturally occurring isomer has the $R R R$-configuration (Fig. 1), whereas tocotrienols have only one anomeric center at carbon 2 [7]. It is generally accepted that the $R R R$ - $\alpha$-tocopherol is the most bioactive compound [8] as it is specifically recognized by membranes [9]. For example, the isomer with inverted stereochemistry at position 2 has only $30 \%$ of the biological activity of the $R R R$ isomer. The synthetic vitamin $E$ ( $\alpha$-tocopherol) is obtained by reaction of trimethylhydroquinone with isophytol [10], without any control of stereochemistry, and comprises a mixture of four pairs of enantiomers in equal amounts (allrac). Synthetic tocopherols are not as biologically active as natural, due to non-active stereoisomers [11].

To increase its stability in the presence of light and oxygen and/or to alter its physical properties such as solubility and miscibility, vitamin E is generally administered as a prodrug in the form of all-rac- $\alpha$-tocopheryl acetate (vitamin E acetate) or all-rac- $\alpha$-tocopheryl succinate (vitamin E succinate). These derivatives carry an acetyl moiety at the C-6 phenolic group that blocks the antioxidant properties [12]. However, unspecific esterases rapidly 
cleave in vivo the ester bond and release the active $\alpha$-tocopherol. The vitamin $E$ acetate is synthesized by chemical acylation of all-rac- $\alpha$-tocopherol with acetic acid or acetic anhydride as acyl donors and a metal catalyst [13]. The enzymatic acetylacion or succinylation of vitamin $\mathrm{E}$ has not been described before, probably due to the large molecular size of the acceptor (tocopherol) and its steric hindrance within the active site of the enzyme.

In the present work, we have studied the enzymatic synthesis of vitamin $\mathrm{E}$ acetate by lipase-catalyzed transesterification and the effect of immobilization carrier and solvent composition on acylation rate. Our results suggest that Candida antarctica lipase B offers appropriate tools for the transformation of vitamin $\mathrm{E}$ under mild conditions. 


\section{EXPERIMENTAL PROCEDURES}

\section{Materials}

Immobilized lipase from C. antarctica B (Novozym 435) was kindly donated by Novozymes A/S. A small sample of lipase B from C. antarctica adsorbed on Accurel EP100 and Purasorb was prepared by Novozymes A/S in the context of the collaborative EU project BIO4-CT980363 following the protocol previously reported [14]. All-rac- $\alpha$-tocopherol was kindly provided by Biotecnologías Aplicadas (BTSA, Madrid, Spain). Tributyrin, RRR- $\alpha$-tocopherol, methyl laurate, propyl laurate and 2-methyl-2-butanol (tert-amyl alcohol) were from Sigma. $(R)-6$ hydroxy-2,5,7,8-tetramethylchromane-2-carboxylic acid $[(R)$-Trolox], vinyl acetate and $p$ cresol were from Aldrich. Solvents were dried over $3 \AA$ molecular sieves. All other reagents were of the highest available purity and used as purchased.

\section{Hydrolytic activity}

The hydrolytic activity was measured titrimetrically at $\mathrm{pH} 7.0$ and $30^{\circ} \mathrm{C}$ using a $\mathrm{pH}$-stat (Mettler, Model DL 50). The reaction mixture consisted of $0.8 \mathrm{ml}$ tributyrin $(64.2 \mathrm{mM}$ final concentration in the vessel), $1.2 \mathrm{ml}$ acetonitrile and $40 \mathrm{ml}$ of $1 \mathrm{mM}$ Tris- $\mathrm{HCl}$ buffer $(\mathrm{pH} 7.0)$ containing $0.1 \mathrm{M} \mathrm{NaCl}$. The immobilized biocatalyst $(5 \mathrm{mg})$ was then added and the $\mathrm{pH}$ automatically maintained at 7.0 using $0.1 \mathrm{~N} \mathrm{NaOH}$ as titrant. Experiments were done in triplicate. One enzyme unit $(U)$ was defined as that catalyzing the formation of $1 \mu \mathrm{mol}$ of fatty acid per min.

\section{Synthetic activity}

To determine the activity in synthesis, methyl laurate $(50 \mathrm{mM})$ and 1-propanol $(50 \mathrm{mM})$ were dissolved in $5 \mathrm{ml}$ hexane in a screw-capped test vial, and stirred for $15 \mathrm{~min}$ at $30^{\circ} \mathrm{C}$. Then, the immobilized biocatalyst $(75 \mathrm{mg})$ was added, and the mixture incubated at $30^{\circ} \mathrm{C}$ and 150 rpm using an orbital shaker (Stuart Scientific). At defined intervals, $50 \mu \mathrm{l}$ aliquots were taken, 
centrifuged and filtered using an eppendorf tube with a $0.45 \mu \mathrm{m}$ filter (Ultrafree-MC, Millipore). The formation of propyl laurate was followed by HPLC. One enzyme unit $(U)$ was defined as that catalyzing the formation of $1 \mu \mathrm{mol}$ of propyl laurate per min.

\section{Water activity}

Water activity was determined using a humidity and temperature digital indicator Novasina Thermoconstanter TH200 (Novasina, Switzerland). The humidity sensor was calibrated with control saturated salts solutions $\left(\mathrm{LiCl}, \mathrm{a}_{\mathrm{w}}=0.11\right.$; potassium acetate, $\mathrm{a}_{\mathrm{w}}=0.22 ; \mathrm{NaBr}, \mathrm{a}_{\mathrm{w}}=0.57$; $\left.\mathrm{NaCl}, \mathrm{a}_{\mathrm{w}}=0.75\right)$ at $25^{\circ} \mathrm{C}$.

\section{Enzymatic acetylation of tocopherols}

Tocopheryl acetate was synthesized by transesterification of vinyl acetate (100-400 mM) with $\alpha$-tocopherol or $\delta$-tocopherol (25-100 mM). Reactions were carried out in 2-methyl-2-butanol (2M2B) in sealed $30 \mathrm{ml}$ dark vials at $60^{\circ} \mathrm{C}$ with orbital stirring (190 rpm). Reaction volume was $5 \mathrm{ml}$. The biocatalyst was added to a final concentration of $100 \mathrm{mg} / \mathrm{ml}$. Aliquots $(200 \mu \mathrm{l})$ were removed at intervals, filtered using an eppendorf tube containing a Durapore ${ }^{\circledR} 0.45 \mu \mathrm{m}$ filter and analyzed by HPLC.

\section{Competitive acetylation experiments}

$\alpha$-Tocopherol or $\delta$-tocopherol $(50 \mathrm{mM})$ and $(R)$-Trolox or $p$-cresol $(50 \mathrm{mM})$ were dissolved in 2M2B containing vinyl acetate $(400 \mathrm{mM})$. Reactions were carried out at $60^{\circ} \mathrm{C}$ with orbital shaking $(190 \mathrm{rpm})$ in sealed $30 \mathrm{ml}$ vials. Reaction volume was $5 \mathrm{ml}$. The biocatalyst was added to a final concentration of $100 \mathrm{mg} / \mathrm{ml}$. Aliquots $(200 \mu \mathrm{l})$ were removed at intervals, filtered using an eppendorf tube with a $0.45 \mu \mathrm{m}$ filter (Ultrafree-MC, Millipore), and analyzed by HPLC. 


\section{HPLC analysis}

For HPLC analysis, a ternary pump (model 9012, Varian) coupled to a thermostatized $\left(15^{\circ} \mathrm{C}\right)$ autosampler (VWR Hitachi L-2200) was used. The temperature of the column was kept constant at $45^{\circ} \mathrm{C}$ (oven model MEF-01, Análisis Vínicos, Spain). Detection was performed using a photodiode array detector (ProStar, Varian), and integration was carried out using the Varian Star LC workstation 6.41. For tocopheryl acetate synthesis, the column was a Lichrospher 100 RP8 (4.6 x 125 mm, $5 \mu \mathrm{m}$, Análisis Vínicos). Mobile phase was 95:5 (v/v) methanol:water (water contained $0.1 \%$ of acetic acid) at $1 \mathrm{ml} / \mathrm{min}$. The reaction products were quantified by measuring the absorbance at $240 \mathrm{~nm}$. For propyl laurate synthesis, the column was a Mediterranea-C18 (4.6 x 150 mm, $5 \mu \mathrm{m}$, Teknokroma, Spain). The mobile phase was 95:5 (v/v) methanol:water (water contained $0.1 \%$ of acetic acid) at $1.2 \mathrm{ml} / \mathrm{min}$, and the analytes were quantified by measuring the absorbance at $216 \mathrm{~nm}$.

\section{HPLC/MS}

To confirm the nature of the acetylated phenolic derivatives, samples were analyzed by HPLC coupled to mass spectrometry (using a HPLC1100 equipment, Agilent Technologies). Chromatographic conditions were as described above, except for the mobile phase contained $1 \%(\mathrm{v} / \mathrm{v})$ formic acid and the flow rate was lowered to $0.6 \mathrm{ml} / \mathrm{min}$. Ionization was performed by electrospray and the mass spectrometer had a hybrid analyzer QTOF model (QSTAR pulsar, Applied Biosystems).

\section{Characterization of immobilized biocatalysts}

Mercury intrusion porosimetry analyses of the biocatalysts were performed using a Fisons Instruments Pascal 140/240 porosimeter. To ensure that the samples were moisture free, they were dried at $100{ }^{\circ} \mathrm{C}$ overnight, prior to measurement. Assuming a cylindrical pore model, the recommended values for the mercury contact angle $\left(141^{\circ}\right)$ and surface tension $(484 \mathrm{mN} / \mathrm{m})$ were used to evaluate the pressure/volume data by the Washburn equation. The 
specific surface area $\left(S_{B E T}\right)$ of the supports was determined from analysis of nitrogen adsorption isotherms at $-196{ }^{\circ} \mathrm{C}$. The samples were previously degassed at $100{ }^{\circ} \mathrm{C}$ for $12 \mathrm{~h}$ to a residual vacuum of $5 \times 10^{-3}$ torr, to remove any loosely held adsorbed species, using a Micromeritics ASAP 2010 device. Water content of the supports was assayed using a DL31 Karl-Fisher titrator (Mettler). Scanning electron microscopy (SEM) was performed using an XL3 microscope (Philips) on samples previously metallized with gold. 


\section{RESULTS AND DISCUSSION}

\subsection{Enzyme screening for acetylation of tocopherols.}

Approximately 15 hydrolases (Table 1) were screened for the transesterification of vinyl acetate with all-rac- $\alpha$-tocopherol in 2-methyl-2-butanol (2M2B). Four esterases from bovine rumen microflora [15] and one from Urania hypersaline basin [16], obtained using metagenomic techniques, were tested . An sterol esterase from the ascomycete Ophiostoma piceae obtained as previously described [17] was also assayed. Some of the hydrolases were previously immobilized in Celite or in epoxy-activated Dilbeads TA [18]. Screening conditions were: $50 \mathrm{mM} \alpha$-tocopherol, $150 \mathrm{mM}$ vinyl acetate, $20 \mathrm{mg} / \mathrm{ml}$ biocatalyst, $40{ }^{\circ} \mathrm{C}$. Among all the enzymes tested, only the immobilized lipase B from C. antarctica (Novozym 435) catalyzed this reaction significantly, although the acylation was slow compared with other processes involving the same biocatalyst and more simple primary or secondary alcohols. For the rest of hydrolases, $\alpha$-tocopherol was probably too large to fit into the acceptor binding site and thus attack the intermediate acetyl-enzyme yielding the tocopheryl ester [19]. The lipases from Candida rugosa and Pseudomonas cepacia, despite their notable transesterification activity towards large hydroxylated substrates [20], did not catalyze the acetylation of vitamin E. By computational conformation studies, it has been demonstrated that the acceptor binding site of lipase B from C. antarctica is deep (compared with other lipases, e.g. from Thermomyces lanuginosus) [21], which partly explains the broader specificity of $C$. antarctica lipase B [22;23]. In addition, Salis et al. reported that the atypical lipase B from C. antarctica is very well adapted for catalysis in organic media [24]. In fact, the lipase B from $C$. antarctica is the preferred biocatalyst for many esterification and transesterification processes [25], including the modification of antioxidants [26-30].

To our knowledge, this is the first evidence on enzymatic acetylation of vitamin $E$. Tocopheryl acetate is normally obtained by a metal-catalyzed reaction using a great excess of acyl donor [31], but these routes do not meet the necessary requirements for food 
applications. In contrast, this biocatalytic process is performed under milder conditions and thus is closer to the green chemistry [32].

\subsection{Effect of acceptor molecular size.}

A comparative study was carried out assaying $\alpha$ - and $\delta$-tocopherol as acceptors under more drastic conditions than in the initial screening. We first analyzed the effect of the molar ratio tocopherol:vinyl acetate (data not shown). We found that a molar ratio 1:4 was optimal in terms of acylation rate without the need of increasing the concentration of acyl donor. Final conditions assayed were: $100 \mathrm{mM}$ tocopherol, $400 \mathrm{mM}$ vinyl acetate, $100 \mathrm{mg} / \mathrm{ml}$ biocatalyst, $60^{\circ} \mathrm{C}$. As shown in Fig. 2, the reaction rate was higher with $\delta$-tocopherol, which rendered $65 \%$ yield of acetylated product in approx. 2 weeks. The reproducibility of the assays was satisfactory, with standard deviations lower than $5 \%$. This different behaviour seems to be related with the lower methylation degree of $\delta$-tocopherol (Fig. 1), which diminishes the steric hindrance within the acceptor binding site.

The molecular weight of the synthesized products was determined by HPLC coupled to mass spectrometry to confirm their chemical nature (Fig. 3). In the case of $\alpha$-tocopherol reaction, the main peak at $m / z 473.44$ corresponded to the $\left([\mathrm{M}+\mathrm{H}]^{+}\right)$of $\alpha$-tocopherol acetate (MW 472.74). For $\delta$-tocopherol acetate (MW 444.68), the main peak in the mass spectrum at $\mathrm{m} / \mathrm{z} 462.44$ corresponded to the $\left(\left[\mathrm{M}+\mathrm{NH}_{4}\right]^{+}\right)$with a minor $\left([\mathrm{M}+\mathrm{H}]^{+}\right)$peak at 445.42 .

It is well known that acyl-transfer reactions catalyzed by $C$. antarctica lipase B follow bi-bi ping-pong mechanism, and the alcohols used as acyl acceptors display competitive substrate inhibition [33]. A series of competitive reactions between tocopherol and other phenolic acceptors were performed to evaluate the effect of molecular size on the acylation rate. $(R)$-Trolox presents the same chromanol ring of $\alpha$-tocopherol -which is responsible of the antioxidant properties- but lacks of the aliphatic chain (Fig. 1), and p-cresol is quite a smaller molecule. Fig. 4 illustrates the reaction progress using the following pairs of acceptors: $\quad \alpha$-tocopherol/(R)-Trolox, $\quad \delta$-tocopherol/(R)-Trolox, $\quad \alpha$-tocopherol $/ p$-cresol, $\quad \delta$ - 
tocopherol/p-cresol. The formation of $(R)$-Trolox acetate and $p$-tolyl acetate was confirmed by HPLC/MS (data not shown). As depicted in Fig. 4, the reaction with Trolox was notably faster than the observed with $\alpha$ - or $\delta$-tocopherol, suggesting that the main steric hindrance is probably caused by the aliphatic chain rather than the chromanol ring. When using a simple phenol such as $p$-cresol, the reaction is nearly one order of magnitude faster than with tocopherols.

\subsection{Effect of immobilization support.}

Immobilization is a suitable approach to expose the enzyme more efficiently to the substrate, being specially indicated for synthetic processes in non-aqueous solvents [34]. Several parameters of immobilized lipases are important to consider for industrial application: mechanical strength, chemical and physical stability, hydrophobic/hydrophilic character, enzyme loading capacity and cost, to cite some. A comparative study with the $C$. antarctica lipase B adsorbed on the ion-exchange resin Lewatit (Novozym 435), polypropylene (Accurel EP100) and Purasorb (a biodegradable polymer based on lactide and glycolide monomers) was performed in the acetylation of $\alpha$-tocopherol (Fig. 5). The hydrolytic activity (measured with tributyrin) of the different immobilizates and their transesterification activity in a model reaction (methyl laurate with propanol in hexane to yield propyl laurate) are reported in Table 2. It is interesting to note that Novozym 435 presents the highest hydrolytic and synthetic activities.

For $\alpha$-tocopherol acetylation, the biocatalysts were first dehydrated to reduce the total amount of water in the system and thus minimize the formation of acetic acid. Final water content was less than $1 \% \mathrm{w} / \mathrm{w}$ (Table 2 ). The hydrolysis of vinyl acetate to acetic acid is an undesirable side reaction also catalysed by the lipase, and competes with the acylation process. Most of the water in the reaction mixture comes from the biocatalyst and the solvents. A careful control of the amount of water in the system -by addition of molecular sieves, drying the biocatalyst, etc.- is crucial in terms of yield and downstream processing 
(the fatty acid must be removed from the final product). It has been reported that dehydration of the biocatalyst in a vacuum dessicator usually increases the transferase to hydrolase ratio [35]. However, water activity $\left(a_{w}\right)$ is preferred to water concentration for describing the hydration level of a system $[14 ; 36]$. We measured the $a_{w}$ of the three biocatalysts assayed, and we found that the values were in the range $0.15-0.25$.

The polypropylene biocatalyst gave rise to faster $\alpha$-tocopherol acetylation than Novozym 435 and Purasorb (Fig. 5). To explain these differences, the textural properties of the biocatalysts were measured by a combination of nitrogen adsorption and mercury porosimetry analyses (Table 2). Fig. 6 represents the total pore volume curves for these carriers. The polypropylene biocatalyst presented a substantially higher total pore volume (approx. $13 \mathrm{~cm}^{3} / \mathrm{g}$ ) than Purasorb $\left(0.8 \mathrm{~cm}^{3} / \mathrm{g}\right)$ and Lewatit $\left(0.6 \mathrm{~cm}^{3} / \mathrm{g}\right)$. The average pore size was also larger for Accurel EP100 and Purasorb (100-900 nm) compared with Novozym 435 $(<100 \mathrm{~nm})$. The SEM pictures showed the presence in polypropylene of a channel structure (with diameters of approx. $10 \mu \mathrm{m}$ ), which facilitates the internal diffusion of substrates and products (Fig. 7). The specific surface area of the three biocatalysts was low $\left(<70 \mathrm{~m}^{2} / \mathrm{g}\right)$ as expected for macroporous carriers. These results may help to explain the differences in acetylation of tocopherols, as large pores facilitate the contact between the enzyme and the bulky acceptor. Compared with the model transesterification reaction involving a small acceptor (propanol) in which Novozym 435 gave the highest activity (Table 2), the Accurel EP100 biocatalyst was the most efficient for acetylation of vitamin E. However, other parameters such as the local effects derived from the chemical nature of the carrier (esp. the hydrophobicity) may also exert an influence on the acylation rate.

\subsection{Effect of medium composition and temperature.}

The mixtures of miscible solvents have been successfully applied to the enzymatic regioselective acylation of several hydroxylic compounds [37-39]. These mixtures represent a compromise between substrates solubility and enzyme efficiency [19]. In the present work, several mixtures $2 \mathrm{M} 2 \mathrm{~B} /$ hexane were assayed in order to favour the solubilization of $\alpha$ - 
tocopherol (Fig. 8). Using Novozym 435 as biocatalyst, the yield was higher when increasing hexane concentration up to $90 \%(\mathrm{v} / \mathrm{v})$. However, a minimum of $10 \%(\mathrm{v} / \mathrm{v}) 2 \mathrm{M} 2 \mathrm{~B}$ was necessary for efficient transesterification, which seems to be related with the solubilization of vinyl acetate.

The effect of temperature (in the range $40-60^{\circ} \mathrm{C}$ ) on $\alpha$-tocopherol acetylation in 2M2B/hexane 90:10 (v/v) was analyzed (Fig. 9). The fastest reaction was observed at $60^{\circ} \mathrm{C}$, at which $C$. antarctica lipase B is known to be highly stable and can be used without significant loss of activity even after several months [40].

\subsection{Enantioselectivity of the process.}

Attempts are being made to develop an efficient and stereocontrolled synthesis of the natural form of $\alpha$-tocopherol [41]. Considering the well-known stereospecificity of lipases [20;42], and in particular of the lipase B from C. antarctica [40;43], one could expect different acetylation rates for the eight stereoisomers present in synthetic all-rac- $\alpha$-tocopherol. We measured the acetylation rate of all-rac- $\alpha$-tocopherol and $R R R$ - $\alpha$-tocopherol to analyze the enantioselectivity of the process. Experimental conditions were: $100 \mathrm{mM} \alpha$-tocopherol, 400 $\mathrm{mM}$ vinyl acetate, hexane/2M2B 90:10 (v/v), $100 \mathrm{mg} / \mathrm{ml}$ Novozym $435,60{ }^{\circ} \mathrm{C}$. We found that the acylation rate was very similar with both substrates (data not shown). This implies that the degree of chiral recognition is low, probably due to the fact that the chiral centers are separated by at least six bonds from the phenolic group that is being acetylated by the lipase (Fig. 1). In this context, Zahalka et al. succeeded in the enantiospecific hydrolysis of $\alpha-$ tocopheryl acetate by a cholesterol esterase [44]. They added chiral bile salts to emulsify the substrate, which may exert influences upon the epimeric acetates induced within the mixed micelle itself, or alternatively, may arise from direct bile salt-enzyme interactions. The nature of the solvent and the length of the acyl donor may also modulate the enantiopurity of the final product [45]. 


\section{ACKNOWLEDGEMENTS}

We are grateful to Morten Christensen and Lotte Andersen (Novozymes A/S) for technical help. We thank Ana V. Ugidos and Soledad Peña (Biotecnologías Aplicadas, BTSA, Spain) for technical information and suggestions. We are grateful to Dr. Karl Hult (Royal Institute of Technology, Sweden) for practical suggestions. We thank Ramiro Martínez (Novozymes A/S

Spain) for technical help. We thank Dr. M. L. Rojas-Cervantes (UNED, Spain) and Dr. M. Yates (ICP, CSIC, Spain) for porosity measurements. This research was supported by the Spanish CSIC (Project 200680F0132) and MEC (Project BIO2002-00337). 


\section{Reference List}

[1] Fang YZ, Yang S, Wu GY. Free radicals, antioxidants, and nutrition. Nutrition $2002 ; 18: 872-879$

[2] Mantovani G, Maccio A, Madeddu C, Mura L, Gramignano G, Lusso MR, Murgia V, Camboni P, Ferreli L, Mocci M, Massa E. The impact of different antioxidant agents alone or in combination on reactive oxygen species, antioxidant enzymes and cytokines in a series of advanced cancer patients at different sites: Correlation with disease progression. Free Radical Res 2003;37:213-223.

[3] Lo Nostro P, Capuzzi G, Romani A, Mulinacci N. Self-assembly and antioxidant properties of octanoyl-6-O-ascorbic acid. Langmuir 2000;16:1744-1750.

[4] Kochhar SP. Stabilisation of frying oils with natural antioxidative components. Eur J Lipid Sci Technol 2000;102:552-559.

[5] Safari M, Karboune S, St Louis R, Kermasha S. Enzymatic synthesis of structured phenolic lipids by incorporation of selected phenolic acids into triolein. Biocatal Biotransfor 2006;24:272-279.

[6] Valentin HE, Qi QG. Biotechnological production and application of vitamin E: current state and prospects. Appl Microbiol Biotechnol 2005;68:436-444.

[7] Weiser H, Vecchi M, Schlachter M. Stereoisomers of alpha-tocopheryl acetate. 4. USP units and alpha-tocopherol equivalents of all-rac-tocopherol, 2-ambo-tocopherol and $R R R$-alpha-tocopherol evaluated by simultaneous determination of resorptiongestation, myopathy and liver-storage capacity in rats. Int $\mathrm{J}$ Vitam Nutr Res 1986;56:45-56. 
[8] Lang JK, Schillaci M, Irvin B. Vitamin E. In: De Leenheer AP, Lambert WE, Nelis HJ, eds. Modern chromatographic analysis of vitamins. New York: Marcel Dekker, Inc.; 1992: p. 153-195.

[9] Cerecetto H, Lopez GV. Antioxidants derived from vitamin E: An overview. Mini-Rev Med Chem 2007;7:315-338.

[10] Bonrath W, Haas A, Hoppmann E, Netscher T, Pauling H, Schager F, Wildermann A. Synthesis of (all-rac)-alpha-tocopherol using fluorinated $\mathrm{NH}$-acidic catalysts. Adv Synth Catal 2002;344:37-39.

[11] Brigelius-Flohe R, Traber MG. Vitamin E: function and metabolism. FASEB J 1999;13:1145-1155.

[12] Schneider C. Chemistry and biology of vitamin E. Mol Nutr Food Res 2005;49:7-30.

[13] Bonrath W, Giraudi L. Process for the manufacture of tocyl and tocopheryl acylates. Patent WO2004/096791. 11-11-2004.

[14] Ferrer M, Plou FJ, Fuentes G, Cruces MA, Andersen L, Kirk O, Christensen M, Ballesteros A. Effect of the immobilization method of lipase from Thermomyces lanuginosus on sucrose acylation. Biocatal Biotransfor 2002;20:63-71.

[15] Ferrer M, Golyshina OV, Chernikova TN, Khachane AN, Reyes-Duarte D, Dos Santos VAPM, Strompl C, Elborough K, Jarvis G, Neef A, Yakimov MM, Timmis KN, Golyshin PN. Novel hydrolase diversity retrieved from a metagenome library of bovine rumen microflora. Environ Microbiol 2005;7:1996-2010.

[16] Ferrer M, Golyshina OV, Chernikova TN, Khachane AN, Dos Santos VAPM, Yakimov MM, Timmis KN, Golyshin PN. Microbial enzymes mined from the Urania deep-sea hypersaline anoxic basin. Chem Biol 2005;12:895-904. 
[17] Calero-Rueda O, Plou FJ, Ballesteros A, Martinez AT, Martinez MJ. Production, isolation and characterization of a sterol esterase from Ophiostoma piceae. BBAProteins Proteom 2002;1599:28-35.

[18] Torres P, Datla A, Rajasekar VW, Zambre S, Ashar T, Yates M, Rojas-Cervantes ML, Calero-Rueda O, Barba V, Martinez MJ, Ballesteros A, Plou FJ. Characterization and application of a sterol esterase immobilized on polyacrylate epoxy-activated carriers (Dilbeads $^{\mathrm{TM}}$ ). Catal Commun 2007;doi:10.1016/j.catcom.2007.07.014.

[19] Plou FJ, Cruces MA, Ferrer M, Fuentes G, Pastor E, Bernabe M, Christensen M, Comelles F, Parra JL, Ballesteros A. Enzymatic acylation of di- and trisaccharides with fatty acids: choosing the appropriate enzyme, support and solvent. J Biotechnol 2002;96:55-66.

[20] $\mathrm{Xu} \mathrm{JH}$, Zhou R, Bornscheuer UT. Comparison of differently modified Pseudomonas cepacia lipases in enantioselective preparation of a chiral alcohol for agrochemical use. Biocatal Biotransfor 2005;23:415-422.

[21] Pleiss J, Fischer M, Schmid RD. Anatomy of lipase binding sites: the scissile fatty acid binding site. Chem Phys Lipids 1998;93:67-80.

[22] Uppenberg J, Ohrner N, Norin M, Hult K, Kleywegt GJ, Patkar S, Waagen V, Anthonsen T, Jones TA. Crystallographic and molecular-modeling studies of lipase B from Candida antarctica reveal a stereospecificity pocket for secondary alcohols. Biochemistry-US 1995;34:16838-16851.

[23] Fuentes G, Ballesteros A, Verma CS. Specificity in lipases: A computational study of transesterification of sucrose. Protein Sci 2004;13:3092-3103. 
[24] Salis A, Svensson I, Monduzzi M, Solinas V, Adlercreutz P. The atypical lipase B from Candida antarctica is better adapted for organic media than the typical lipase from Thermomyces lanuginosa. BBA-Proteins Proteom 2003;1646:145-151.

[25] Belafi-Bako K, Kovacs F, Gubicza L, Hancsok J. Enzymatic biodiesel production from sunflower oil by Candida antarctica lipase in a solvent-free system. Biocatal Biotransfor 2002;20:437-439.

[26] Adamczak M, Bornscheuer UT, Bednarski W. Synthesis of ascorbyl oleate by immobilized Candida antarctica lipases. Process Biochem 2005;40:3177-3180.

[27] Chebil L, Humeau C, Falcimaigne A, Engasser JM, Ghoul M. Enzymatic acylation of flavonoids. Process Biochem 2006;41:2237-2251.

[28] Reyes-Duarte D, Lopez-Cortes N, Ferrer M, Plou FJ, Ballesteros A. Parameters affecting productivity in the lipase-catalysed synthesis of sucrose palmitate. Biocatal Biotransfor 2005;23:19-27.

[29] Teng RW, Bui TKA, McManus D, Armstrong D, Mau SL, Bacic A. Regioselective acylation of several polyhydroxylated natural compounds by Candida antarctica lipase B. Biocatal Biotransfor 2005;23:109-116.

[30] Ferrer M, Soliveri J, Plou FJ, Lopez-Cortes N, Reyes-Duarte D, Christensen M, Copa-Patino JL, Ballesteros A. Synthesis of sugar esters in solvent mixtures by lipases from Thermomyces lanuginosus and Candida antarctica B, and their antimicrobial properties. Enzyme Microb Tech 2005;36:391-398.

[31] Oost, C., Kaibel, G., Laas, H., Schmitt, P., and von Erden, J. Method for continuously acylating chromanol ester derivatives. Patent US2004/0014996. 22-1-2004. 
[32] Alcalde M, Ferrer M, Plou FJ, Ballesteros A. Environmental biocatalysis: from remediation with enzymes to novel green processes. Trends Biotechnol 2006;24:281287.

[33] Martinelle M, Hult K. Kinetics of acyl transfer-reactions in organic media catalyzed by Candida antarctica lipase B. BBA-Protein Struct M 1995;1251:191-197.

[34] Persson M, Mladenoska I, Wehtje E, Adlercreutz P. Preparation of lipases for use in organic solvents. Enzyme Microb Tech 2002;31:833-841.

[35] Rizzi M, Stylos P, Riek A, Reuss M. A kinetic-study of immobilized lipase catalyzing the synthesis of isoamyl acetate by transesterification in normal-hexane. Enzyme Microb Tech 1992;14:709-714.

[36] Chamouleau F, Coulon D, Girardin M, Ghoul M. Influence of water activity and water content on sugar esters lipase-catalyzed synthesis in organic media. J Mol Catal BEnzym 2001;11:949-954.

[37] Ferrer M, Cruces MA, Bernabe M, Ballesteros A, Plou FJ. Lipase-catalyzed regioselective acylation of sucrose in two-solvent mixtures. Biotechnol Bioeng 1999;65:10-16.

[38] Pedersen NR, Wimmer R, Emmersen J, Degn P, Pedersen LH. Effect of fatty acid chain length on initial reaction rates and regioselectivity of lipase-catalysed esterification of disaccharides. Carbohydr Res 2002;337:1179-1184.

[39] Castillo E, Pezzotti F, Navarro A, Lopez-Munguia A. Lipase-catalyzed synthesis of xylitol monoesters: solvent engineering approach. J Biotechnol 2003;102:251-259.

[40] Anderson EM, Karin M, Kirk O. One biocatalyst - Many applications: The use of Candida antarctica B-lipase in organic synthesis. Biocatal Biotransfor 1998;16:181204. 
[41] Nozawa M, Takahashi K, Kato K, Akita $H$. Enantioselective synthesis of $\left(2 R, 4^{\prime} R, 8^{\prime} R\right)-$ alpha-tocopherol (vitamin E) based on enzymatic function. Chem Pharm Bull 2000;48:272-277.

[42] Miyazawa T, Yukawa T, Yamada T. Resolution of 2-phenoxy-1-propanols through the enantioselective acylation mediated by Achromobacter sp lipase as biocatalyst. Biocatal Biotransfor 2006;24:231-235.

[43] Cross H, Marriott R, Grogan G. Enzymatic esterification of lavandulol - a partial kinetic resolution of (S)-lavandulol and preparation of optically enriched $(R)$-lavandulyl acetate. Biotechnol Lett 2004;26:457-460.

[44] Zahalka HA, Dutton PJ, Odoherty B, Smart TAM, Phipps J, Foster DO, Burton GW, Ingold KU. Bile-salt modulated stereoselection in the cholesterol esterase catalyzedhydrolysis of alpha-tocopherol acetates. J Am Chem Soc 1991;113:2797-2799.

[45] Ottosson J, Hult K. Influence of acyl chain length on the enantioselectivity of Candida antarctica lipase B and its thermodynamic components in kinetic resolution of secalcohols. J Mol Catal B-Enzym 2001;11:1025-1028. 
Table 1. Screened hydrolases for acetylation of $\alpha$-tocopherol

\begin{tabular}{lll}
\hline Enzyme & Physical state & Origin \\
\hline Lipase B from Candida antarctica & Immobilized (Novozym 435) & Novozymes A/S \\
Lipase from Thermomyces lanuginosus & Immobilized (Lipozyme TL IM) & Novozymes A/S \\
Lipase from Rhizomucor miehei & Immobilized (Lipozyme RM IM) & Novozymes A/S \\
Lipase from Pseudomonas cepacia & Immobilized (Lipase I PS-C) & Amano \\
Lipase from Alcaligenes sp. & Immobilized (Lipase PLG) & Meito Sangyo \\
Lipase from Alcaligenes sp. & Immobilized (Lipase QLG) & Meito Sangyo \\
Cholesterol esterase from Pseudomonas sp. & Powder & Sigma \\
Cholesterol esterase from Ophiostoma piceae & Immobilized in Dilbeads TA & Fermentation \\
Lipase from porcine pancreas & Powder & Sigma \\
Lipase from Candida rugosa & Powder & Sigma \\
Protease from Bacillus licheniformes & Immobilized in Dilbeads TA & Sigma \\
Esterases from bovine rumen microflora & Immobilized in Dilbeads TA & Metagenome \\
Esterases from bovine rumen microflora & Immobilized in Celite & Metagenome \\
Esterase from Urania hypersaline basin & Lyophilized & Metagenome \\
\hline
\end{tabular}


Table 2. Properties of the $C$. antarctica lipase B (CALB) immobilizates.

\begin{tabular}{|c|c|c|c|c|c|c|}
\hline \multirow{2}{*}{ Immobilizate } & \multirow{2}{*}{$S_{\mathrm{BET}}\left(\mathrm{m}^{2} / \mathrm{g}\right)^{\mathrm{a}}$} & \multirow{2}{*}{$\begin{array}{l}\text { Pore volume } \\
\qquad\left(\mathrm{cm}^{3} / \mathrm{g}\right)^{\mathrm{b}}\end{array}$} & \multicolumn{2}{|c|}{ Water content $(\%)^{\mathrm{C}}$} & \multirow{2}{*}{$\begin{array}{l}\text { Hydrolytic activity } \\
{\text { (U/g biocatalyst })^{d}}^{\text {(U) }}\end{array}$} & \multirow{2}{*}{$\begin{array}{c}\text { Transesterification } \\
\text { activity } \\
\text { (U/g biocatalyst) }^{\mathrm{e}}\end{array}$} \\
\hline & & & Before & After & & \\
\hline Novozyme 435 & 68.6 & 0.6 & 2.2 & 0.9 & 2950 & 31.3 \\
\hline $\begin{array}{c}\text { CALB/Accurel } \\
\text { EP100 }\end{array}$ & 67.8 & 13 & 1.9 & 0.7 & 2310 & 29.4 \\
\hline CALB/Purasorb & 9.2 & 0.8 & 0.9 & 0.3 & 300 & 21.8 \\
\hline
\end{tabular}

${ }^{\text {a }}$ Measured by $\mathrm{N}_{2}$ adsorption.

${ }^{b}$ By combination of $\mathrm{N}_{2}$ isotherms and $\mathrm{Hg}$ porosimetry.

${ }^{\mathrm{c}}$ Determined by Karl-Fisher titration before and after dehydration.

${ }^{\mathrm{d}}$ Measured with tributyrin.

${ }^{\mathrm{e}}$ Measured in the test reaction between methyl laurate and 1-propanol. 


\section{Figure legends}

Fig. 1. Structure of $\alpha$ - and $\delta$-tocopherol (the location of the three chiral centers is marked with an asterisk), $(R)$-Trolox and $p$-cresol.

Fig. 2. Kinetics of $\alpha$-tocopherol $(\mathbf{O})$ and $\delta$-tocopherol $(\bullet)$ acetylation in 2M2B catalyzed by Novozym 435. Experimental conditions: $100 \mathrm{mM} \alpha$ - or $\delta$-tocopherol, $400 \mathrm{mM}$ vinyl acetate, $100 \mathrm{mg} / \mathrm{ml}$ Novozym $435,60^{\circ} \mathrm{C}$.

Fig. 3. Molecular weight determination of $\alpha$-tocopheryl acetate $(A)$ and $\delta$-tocopheryl acetate (B) using HPLC-MS.

Fig. 4. Competitive acetylation reactions in 2M2B between tocopherols and $(R)$-Trolox or $p$ cresol catalyzed by Novozym 435. Experimental conditions: $50 \mathrm{mM} \alpha$ - or $\delta$-tocopherol, 50 $\mathrm{mM}(R)$-Trolox or $p$-cresol, $400 \mathrm{mM}$ vinyl acetate, $100 \mathrm{mg} / \mathrm{ml}$ Novozym $435,60^{\circ} \mathrm{C}$.

Fig. 5. Kinetics of $\alpha$-tocopheryl acetate synthesis in 2M2B catalyzed by $C$. antarctica lipase B immobilized in three different supports: (A ) Accurel EP100; (0) Lewatit (Novozym 435);

Purasorb. Experimental conditions: $100 \mathrm{mM} \alpha$-tocoferol, $400 \mathrm{mM}$ vinyl acetate, $100 \mathrm{mg} / \mathrm{ml}$ biocatalyst, $60^{\circ} \mathrm{C}$.

Fig. 6. Total pore volume of the biocatalysts determined by combination of $\mathrm{N}_{2}$ adsorption and mercury intrusion porosimetry data. (A) Novozym 435; (B) CALB/Purasorb; (C) CALB/Accurel EP100.

Fig. 7. Scanning electron micrographs of the biocatalysts studied (A) 60x; (B) 500x. 
Fig. 8. Effect of hexane percentage $(\mathrm{v} / \mathrm{v})$ in mixtures 2M2B/hexane on $\alpha$-tocopheryl acetate synthesis. Experimental conditions: $100 \mathrm{mM} \alpha$-tocopherol, $400 \mathrm{mM}$ vinyl acetate, $100 \mathrm{mg} / \mathrm{ml}$ Novozym $435,60^{\circ} \mathrm{C}$. Yields refer to 6 days reaction.

Fig. 9. Effect of temperature on $\alpha$-tocopheryl acetate synthesis in hexane/2M2B 90:10 (v/v). Experimental conditions: $100 \mathrm{mM} \alpha$-tocopherol, $400 \mathrm{mM}$ vinyl acetate, $100 \mathrm{mg} / \mathrm{ml}$ Novozym 435. (•) $40^{\circ} \mathrm{C} ;(\mathbf{O}) 50^{\circ} \mathrm{C} ;(\boldsymbol{\bullet}) 60^{\circ} \mathrm{C}$ 
Fig. 1
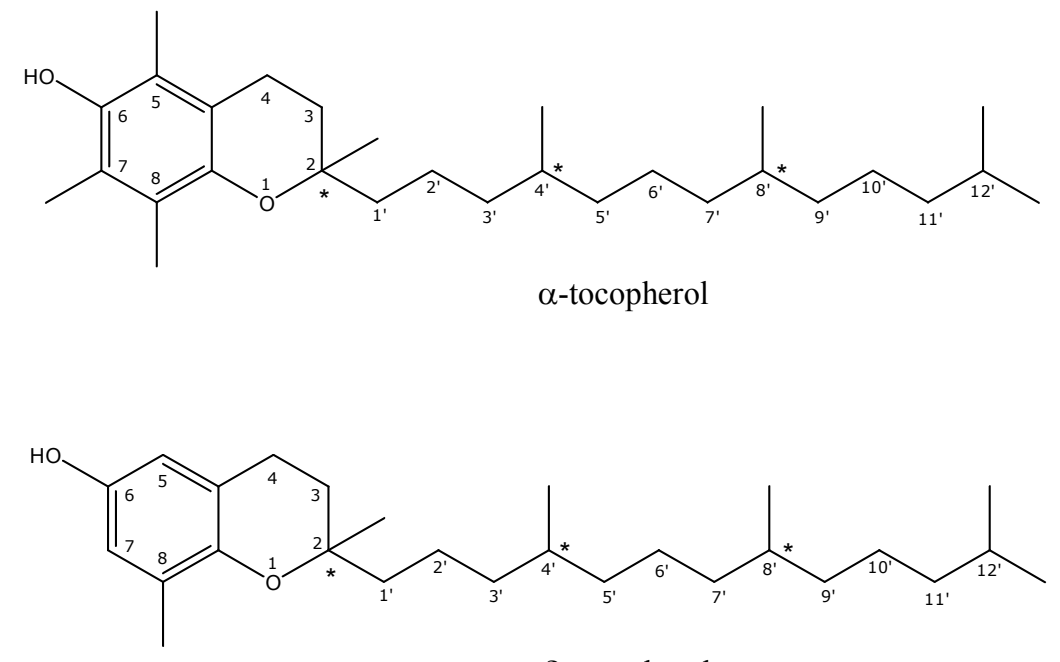

$\delta$-tocopherol<smiles>Cc1c(C)c2c(c(C)c1O)CC[C@](C)(C(=O)O)O2</smiles>

(R)-Trolox

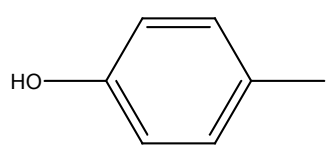

p-cresol 
Fig. 2

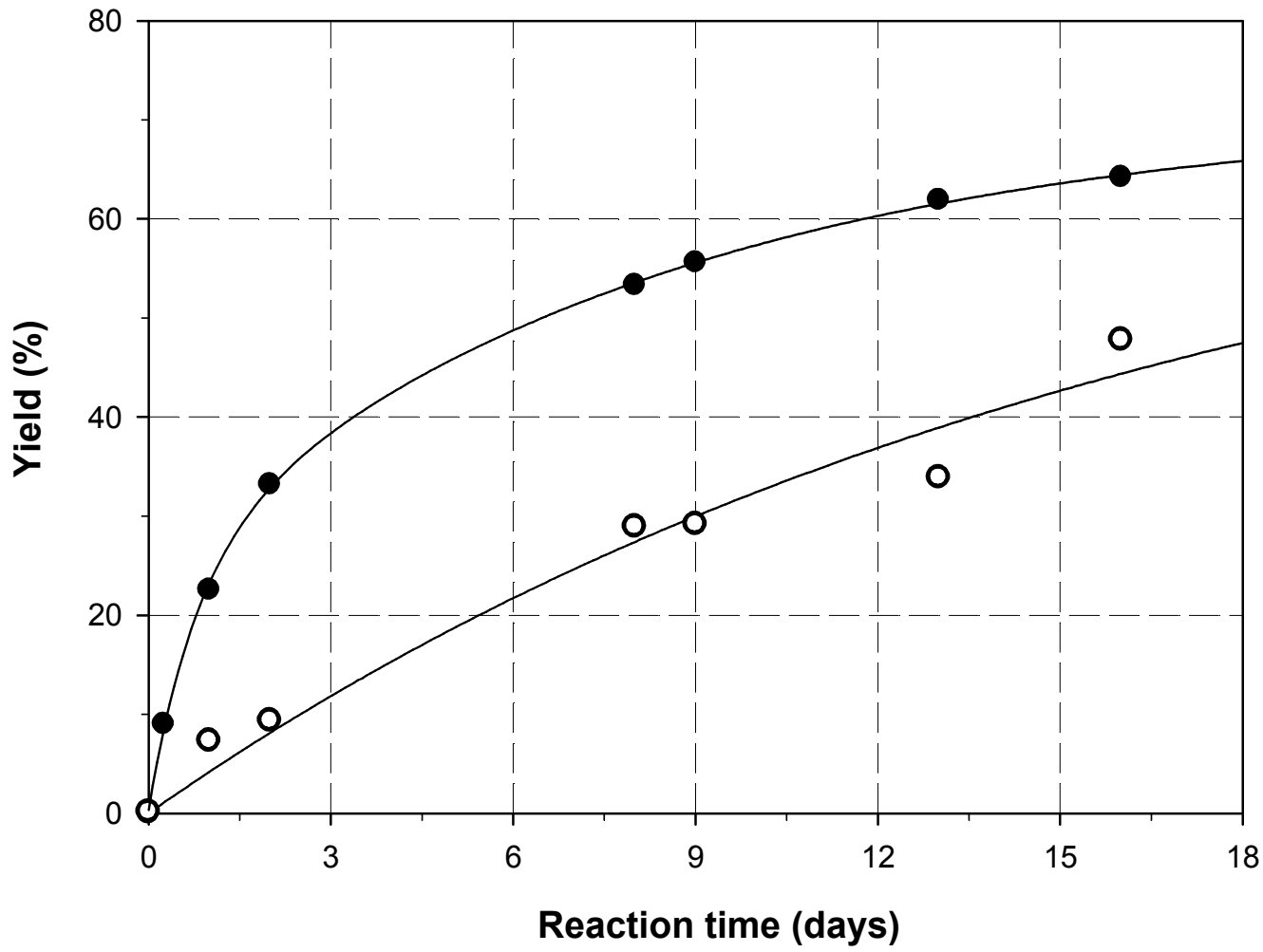


Fig. 3
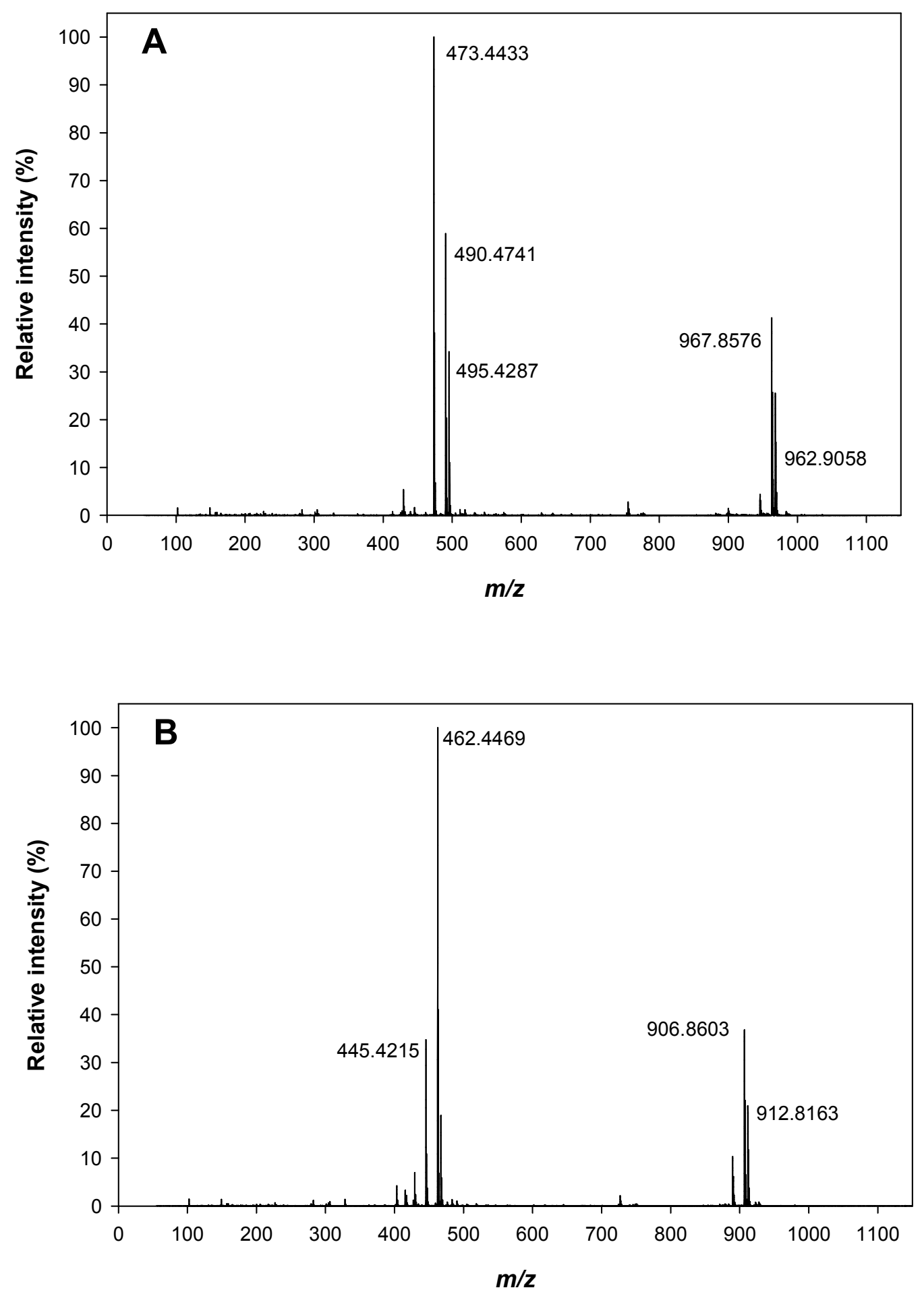
Fig. 4
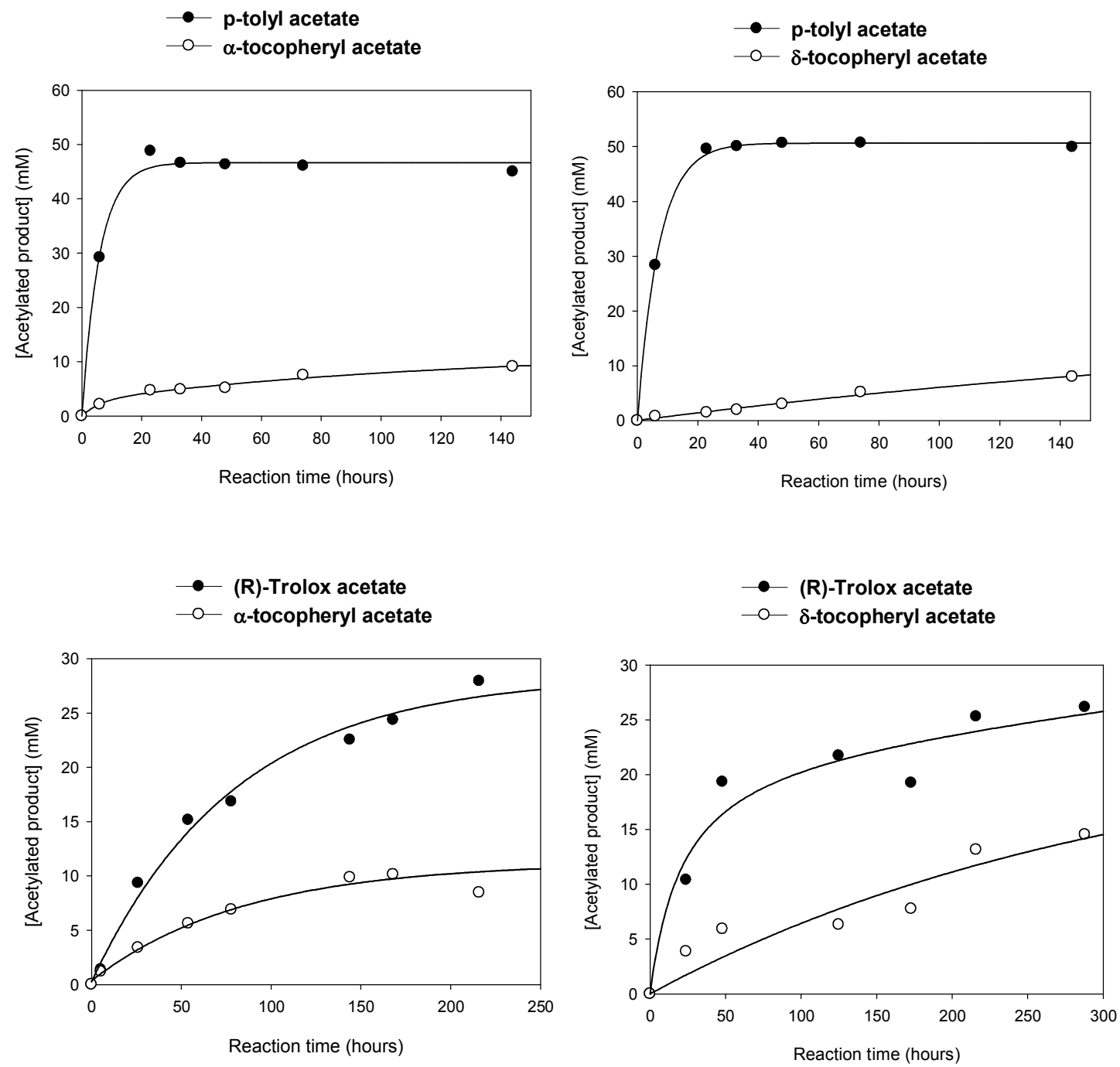
Fig. 5

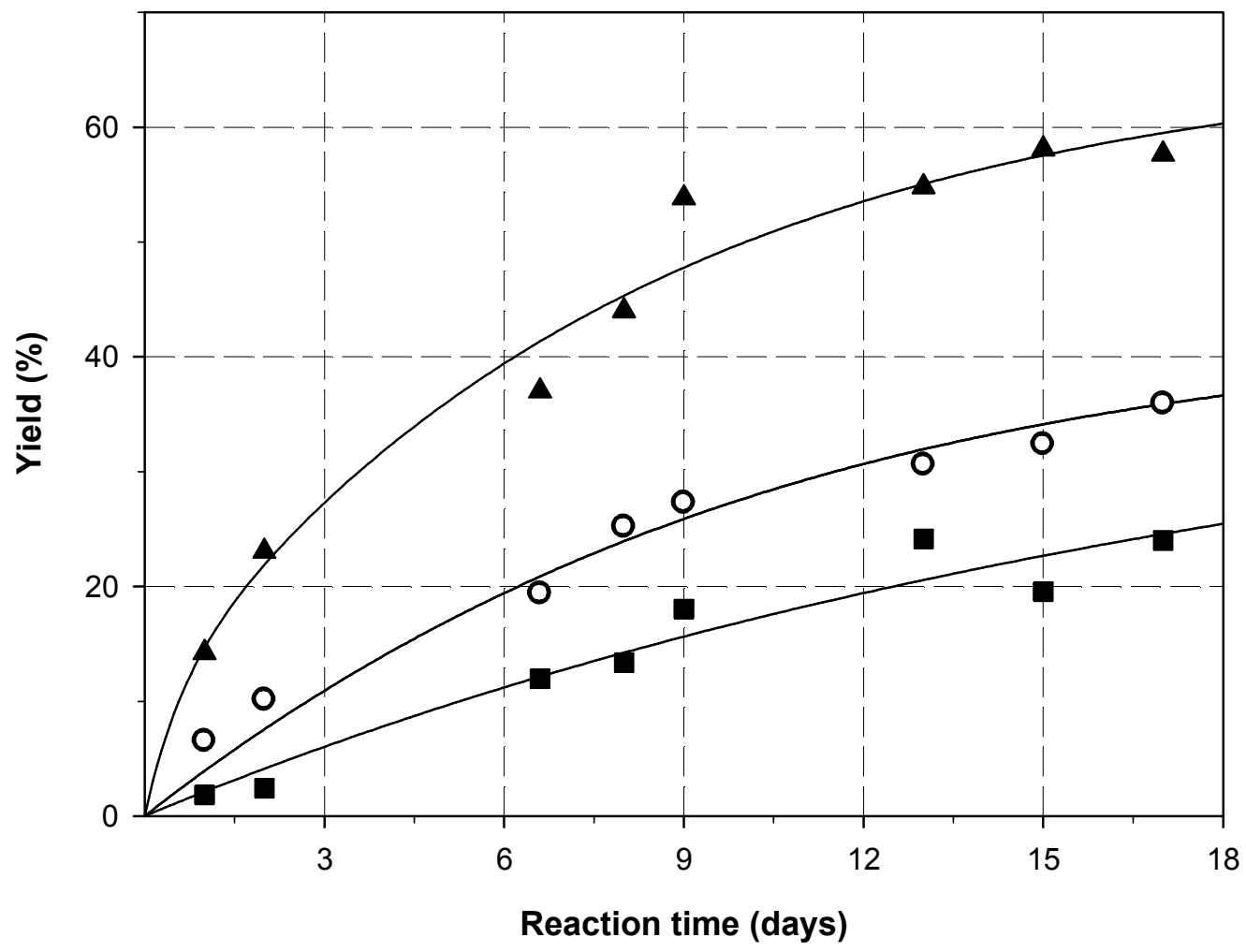


Fig. 6
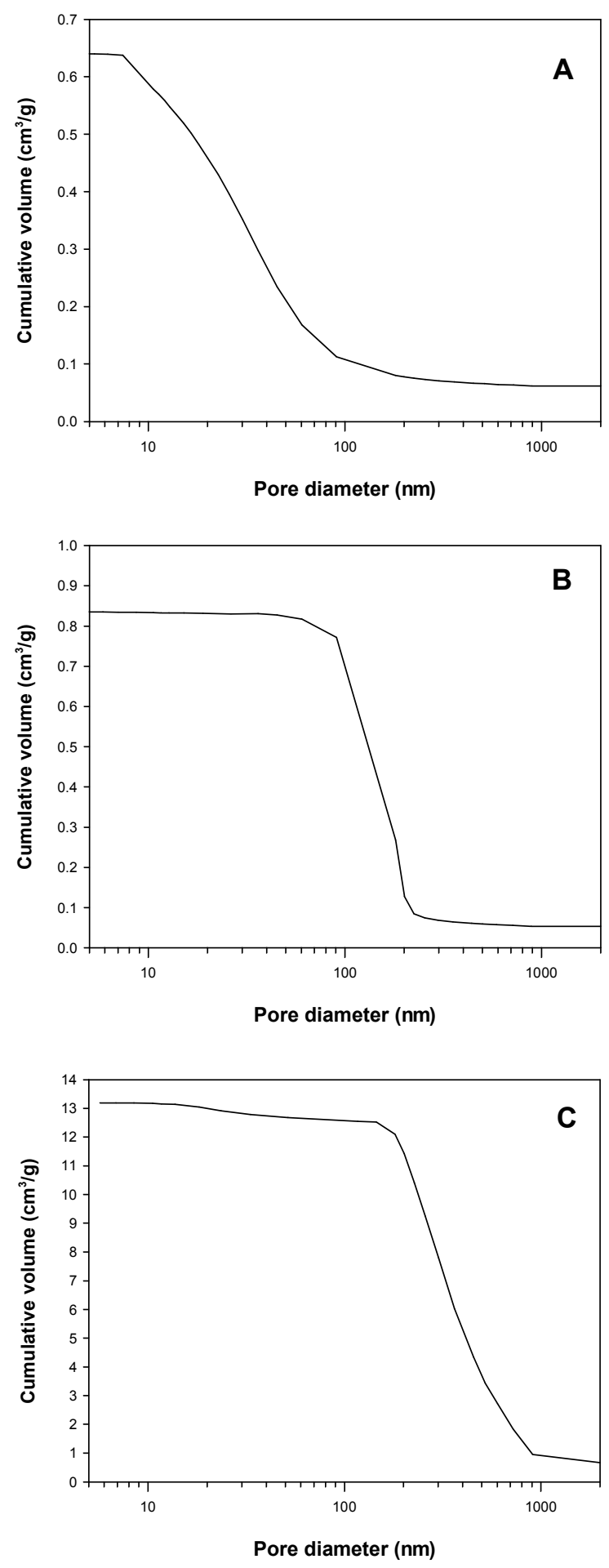
Fig. 7
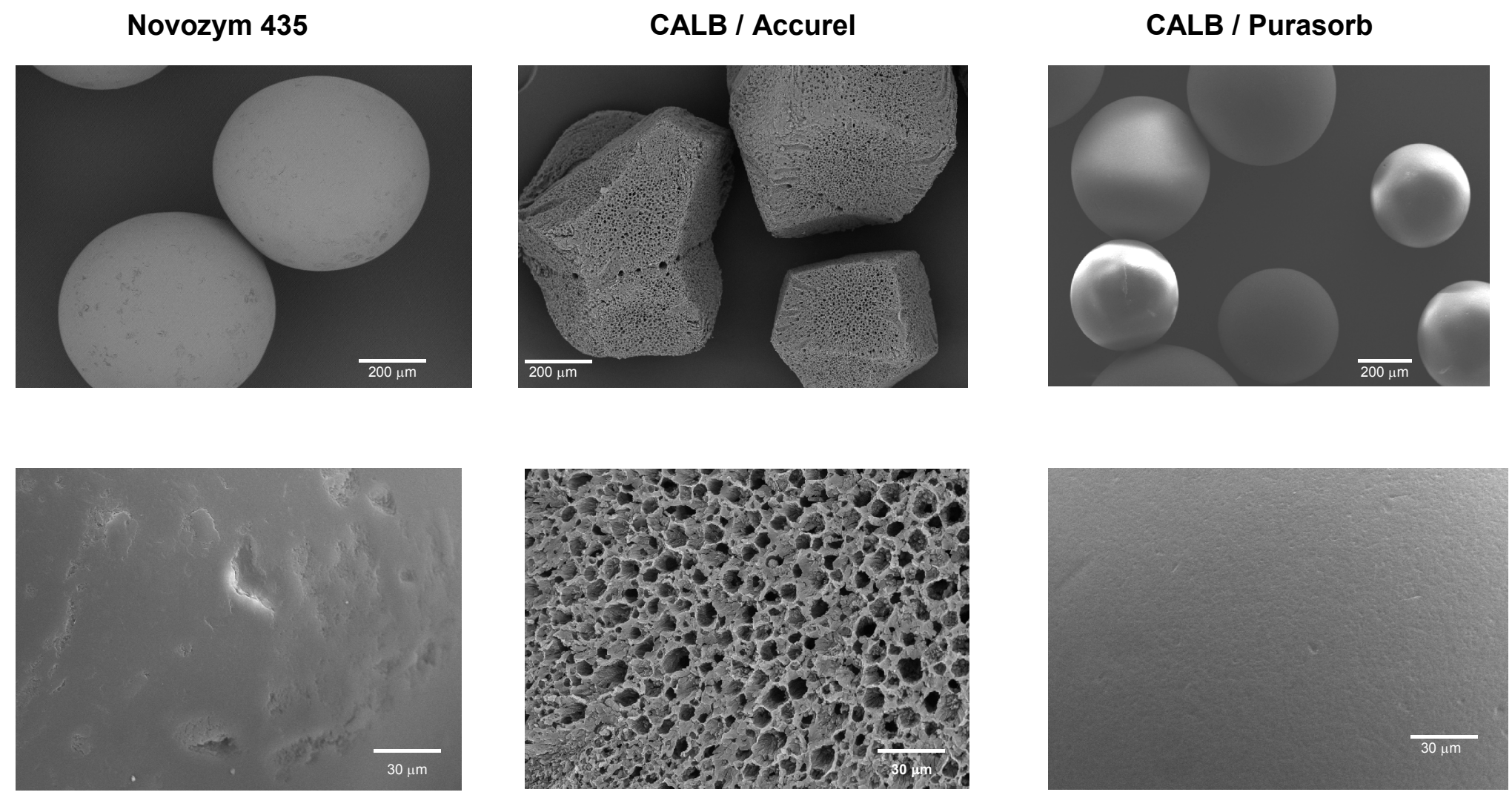
Fig. 8

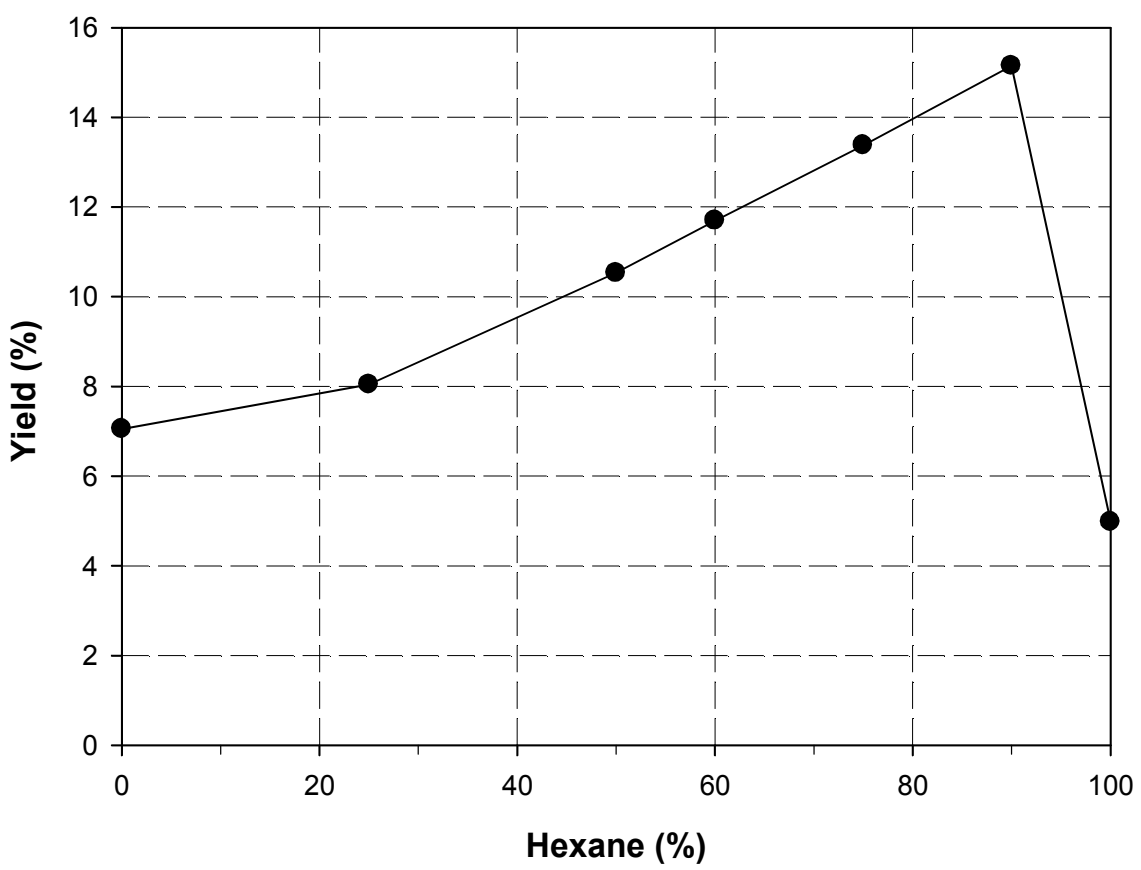


Fig. 9

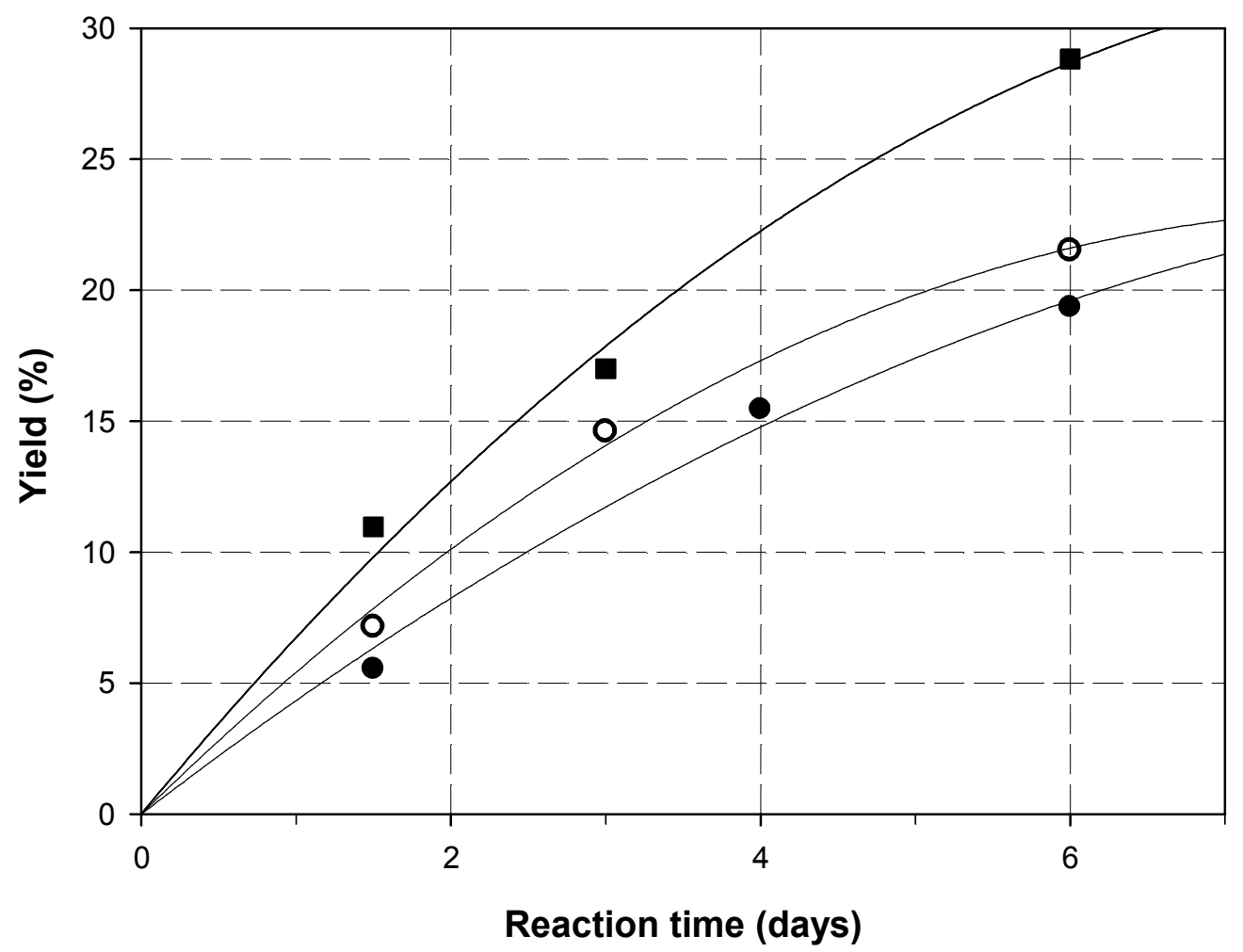

